\title{
THE EFFECT OF COMMERCIAL ORGANIC AND INORGANIC FERTILIZERS AND RHIZOBIUM INOCULATION ON YIELD AND YIELD COMPONENTS OF FABA BEAN (VICIA FABA L.) AND PEA (PISUM SATIVUM L.)
}

\author{
F. BASDEMIR ${ }^{1}$, S. ELIS ${ }^{2}$, S. IPEKESEN ${ }^{2}$, M. TUNC ${ }^{2}$, B.T. BICER ${ }^{2 *}$
}

*E-mail: tbicer@dicle.edu.tr

Received: July 15, 2020. Revised: Sept. 29, 2020. Accepted: Oct. 06, 2020. Published online: Oct. 16, 2020

\begin{abstract}
This research was conducted to determine the effect of organic and inorganic fertilizers and bacteria inoculation on yield and its components on pea and faba bean in Dicle University Agricultural Faculty, Diyarbakir, Turkey, during 2018 and 2019 growing seasons. The experiment was laid out following a split-plot in completely randomized block design, with three replications. Fertilization treatments and cultivars were designed as main and sub factors, respectively. Data on plant height, plant biomass, pod weight, seed yield per plant, number of pods and number of seeds per plant, biological yield, seed yield and 100-seed weight were recorded at harvest. Number

significant at both pea and faba bean. Inorganic fertilizer (urea) was increased the grain yield (2147 kg/ha) and biological yield (4956 kg/ha) in faba bean, but close to control (2080 kg/ha and $4690 \mathrm{~kg} / \mathrm{ha}$ ). Organic-1, Organic-2 and bacteria treatments were decrease the grain yield and biological yield on pea and faba bean, and this decrease on pea was almost half over control. The effect of treatments on number of nodules per plant on pea and faba bean was significant. The highest number of nodules per plant on pea was in bacteria inoculation (125.9) and control (121.5), and differences among nitrogen (109.1), Organic-1 (97.3) and Organic-2 (109.3) treatments was no significant.
\end{abstract} of nodules and nodule dry weight were record in flowering time. The effect of inorganic nitrogen, organic fertilizers and bacteria inoculation on grain yield, seed yield per plant, biological yield was

Keywords: pea; faba bean; fertilization; nodule; yield.

\footnotetext{
${ }^{1}$ Harran University, Ceylanpinar Vocational School Sanliurfa, Turkey

${ }^{2}$ Dicle University, Faculty of Agriculture, Department of Field Crops, Diyarbakir, Turkey
} 


\section{INTRODUCTION}

Legumes are an important source of protein for humans and livestock. They provide nutritionally rich crop residues for animal feed and also humans and play a key role in maintaining the productivity of soil (Elsheikh, 2011).

Field pea and faba bean are marketed as a dry, shelled product for food. They are commonly used throughout the world in human diets and have high levels of amino acids, lysine and tryptophan, which are relatively low in cereal grains and contains approximately 21-25\% protein. Being legume crops and have the inherent ability to obtain much of its nitrogen requirement from the atmosphere by forming a symbiotic relationship with Rhizobium bacteria in the soil (Mishra et al., 2010)

Poor soil fertility is one of the biggest problems limiting economically successful agricultural production worldwide. The lack of nutrients in the soil is a specific problem for small farmers which have small landowners in developing countries where monoculture farming is high.

Fertilizer is very important for crop growth and productivity. One example of fertilizer is cow dung, which is obtained from cow, which is environmental friendly, is easily used and compared with chemical fertilizer which increases the environmental problems. Organic fertilizers are used easily from locality products and livestock wastes and cost effective than chemical fertilizer (Solomon et al., 2012).

One of the immediate reasoning to improve agricultural productivity and development is the use of more chemical fertilizers. However, with the resultant effects of heavy fertilizer use in many regions of the world, it is compelling to look for alternatives. Integration of microbial inoculants with less fertilizer, should be considered in many situations as it promises high crop productivity and agricultural sustainability (Adesemoyeetal., 2009).

The reduction of chemical fertilizers by using biological fertilizers based on bacteria involved in nitrogen fixation is one of the effective steps in sustainable agriculture. Owing to population growth and increasing food demand, intensive and environment-friendly agricultural bio-fertilizers have become the ideal model for this agriculture system (Adesemoye and Egamberdieva, 2013).

Recently, organic fertilizers, as alternatives to chemical fertilizers and especially the growing of legumes that have an important place in the nitrogen cycle, are examined (Silsbury, 1990). The choices of suitable forms of fertilizer of the crop growth of the plant are governed by local, natural condition and variation in soil and climate with regard to their suitability for crops cultivation.

Biofertilizers are organic products, containing living cells of different types of microorganisms, which have the ability to convert 
nutritionally important elements from unavailable to available form, through biological processes (Vessey, 2003). The Rhizobium, as fertilizer in pulses, could fix $50-200 \mathrm{~kg}$ of $\mathrm{N} / \mathrm{ha} / \mathrm{season}$ and is able to meet $80-90 \%$ of the crop requirement for nitrogen. Inoculation in these crops was found to increase the crop yield by about $10-15 \%$, under on farm conditions (Khurana and Dudeja, 1997).

The humic substances are formed through the chemical and biological transformation of plant and animal matter by the biological activities of microorganisms. These substances influence plant growth directly and indirectly. Humic acid is an important component of humic substances that contains many functional groups situated at the carbon chain. They could be acidic, alkaline or neutral groups, which improve plant growth (Patil et al., 2011).

The present study was conducted to determine the effects of organic and inorganic fertilizers and rhizobium inoculation on grain yield and its components of faba bean and pea crops.

\section{MATERIALS AND METHODS}

This research was conducted to determine the effect of organic and inorganic fertilizers and bacteria inoculation on yield and its components on pea and faba bean crops in Dicle University, Agricultural Faculty, Diyarbakir, Turkey, during 2018 and 2019 growing seasons.

\section{Experimental area}

Diyarbakir is located on grid $37.91^{\circ} \mathrm{N}$ and $40.2^{\circ} \mathrm{E}$, at an altitude of
$640 \mathrm{~m}$ above sea level. The general climatic conditions of experimental area were characterized as hot and drought, during crop growing season. Average long term precipitation is a little bit lower than $500 \mathrm{~mm}$, and it differently fluctuates among the years. The seasonal rainfall distribution is mainly between November and June. Although unusual, irregular precipitation in June is recorded in recent years. Mean temperature is about $16-20^{\circ} \mathrm{C}$, between January and June. Month of May has an irregular precipitation distribution, but June is usually dry and hot. The relative humidity varies between $60 \%$ and $75 \%$, from January to April, but decreases to about $20-30 \%$, after May. In the first experiment year (2018), total precipitation from February to April was $146.8 \mathrm{~mm}$, and weather was dry, but in May, rainfall was $157.8 \mathrm{~mm}$. Mean temperature (February to May) was $11.9^{\circ} \mathrm{C}$. Precipitation from February to April was $365.2 \mathrm{~mm}$, in the second year (2019), but May was considerably dry, with $45.8 \mathrm{~mm}$, and mean temperature (February to May) was $11.35^{\circ} \mathrm{C}$. Growing season in 2019 was quite cool, compared to the preceding growing season (Table 1).

The soil analysis indicated that soils were neutral chemical reaction ( $\mathrm{pH}: 7.24)$, insufficient in organic matter (0.79\%) and phosphorus content (13.2 kg ha $\left.{ }^{-1}\right)$, with clay texture.

\section{Experimental design and agricultural practices}

The experiment was laid out following a split-plot in completely randomized block design, with three replications. Fertilization treatments and cultivars were designed as main and sub factors, respectively. Fertilization treatments included of control, inorganic nitrogen as urea, Organic-1, Organic-2 fertilizers and bacteria application. Local varieties of pea and faba bean, collected 


\section{ORGANIC AND INORGANIC FERTILIZATION ON FABA BEAN AND PEA}

from villages of Mediterranean region of Turkey, were used. The seeds were sown with inter and intra row space of $40 \times 10 \mathrm{~cm}$, respectively, on 7 February 2018 and 11 February 2019 (Albayrak et al., 2015).

Before sowing, seeds were inoculated with specific strains of Rhizobium (R. leguminosarum and R. pisi) at a rate of $10 \mathrm{~g} / \mathrm{kg}$ seed as bacteria treatment both pea and faba bean. Inorganic nitrogen were applied at a rate of $40 \mathrm{~kg} \mathrm{ha}^{-1}$ as urea (46\%). Organic-1 fertilizer was consisted of organic materials (45\%), organic carbon (20\%), organic nitrogen (6\%), free amino acids (3.5\%) and $\mathrm{pH}$ (6-8). Organic-2 fertilizer was contained $45-50 \%$ organic material and \%50 fulvic acid. Weed, disease and pests were controlled first manually and then using chemical spray. Data on plant height, plant biomass, pod weight, seed yield per plant, number of pods and number of seeds per plant, biological yield, seed yield and 100 -seed weight were recorded at harvest.

Data of two years were analyzed separately and pooled by analysis of variance, and means were separated using the Duncan's Multiple Range Test (0.05).

Table 1 - Meteorological data of Diyarbakir for experiment years

\begin{tabular}{lcccccc}
\hline \multirow{2}{*}{ Month } & \multicolumn{2}{c}{ Mean temperature $\left({ }^{\circ} \mathbf{C}\right)$} & \multicolumn{2}{c}{ Total precipitation $(\mathbf{m m})$} & \multicolumn{2}{c}{ Moisture (\%) } \\
\cline { 2 - 7 } & $\mathbf{2 0 1 8}$ & $\mathbf{2 0 1 9}$ & $\mathbf{2 0 1 8}$ & $\mathbf{2 0 1 9}$ & $\mathbf{2 0 1 8}$ & $\mathbf{2 0 1 9}$ \\
\hline January & 5.2 & 3.8 & 86.6 & 67.6 & 77.3 & 81.7 \\
\hline February & 7.6 & 5.4 & 86.4 & 77.4 & 74.5 & 77.0 \\
\hline March & 12.3 & 8.2 & 11.6 & 135.2 & 63.2 & 74.9 \\
\hline April & 15.9 & 11.8 & 48.8 & 152.6 & 53.0 & 78.4 \\
\hline May & 19.4 & 20.1 & 157.8 & 45.8 & 67.5 & 58.5 \\
\hline June & 26.5 & 28.3 & 14.4 & 1.0 & 37.9 & 32.5 \\
\hline July & 31.2 & 30.3 & 0.0 & 0.07 & 24.2 & 24.8 \\
\hline
\end{tabular}

\section{RESULTS AND DISCUSSION}

The effect of inorganic nitrogen, organic fertilizers and bacteria inoculation on grain yield, seed yield per plant, biological yield was significant at both pea and faba bean. The effect of treatments on plant biomass was significant on faba bean.

Inorganic fertilizer (urea) was increased the grain yield (2147 kg/ha) and biological yield (4956 kg/ha) in faba bean, but close to control (2080 kg/ha and $4690 \mathrm{~kg} / \mathrm{ha}$ ). Organic-1, Organic-2 and bacteria treatments were decrease the grain yield and biological yield on pea and faba bean, and this decrease on pea was almost half over control.
The lowest grain yield on pea and faba bean was in Organic-2 treatment (882 kg/ha and $1819 \mathrm{~kg} / \mathrm{ha})$ and bacteria inoculation $(896 \mathrm{~kg} / \mathrm{ha}$ and $1771 \mathrm{~kg} / \mathrm{ha}$ ). The lowest biological yield on pea and faba bean was in bacteria inoculation (2664 kg/ha and $3867 \mathrm{~kg} / \mathrm{ha}$ ) (Fig. 1).

Lal et al. (2004) and Servani et al. (2014) reported that grain yield increased by nitrogen applications. Ngeno et al. (2012) reported that bacteria application was no increased the seed yield. Brkić et al. (2004) reported that the effect of nitrogen fertilization depended on the soil type, seed inoculation and molybdenum application increased pea yield. 
Organic-1 and Organic-2 fertilizers, which involved humic acid, showed low performance the yield and its components in our study, this may be due to the application dose and the time of application of the fertilizer. Whereas, Patil et al., Wadje (2011) revealed humic acid is an important component of humic substances that contains many functional groups situated at the carbon chain, and they could be acidic, alkaline or neutral groups, which improve plant growth. Differences among years and treatment $\times$ year interaction were significant for grain yield, biological yield, plant biomass and seed yield per plant both faba bean and pea (Table 2).

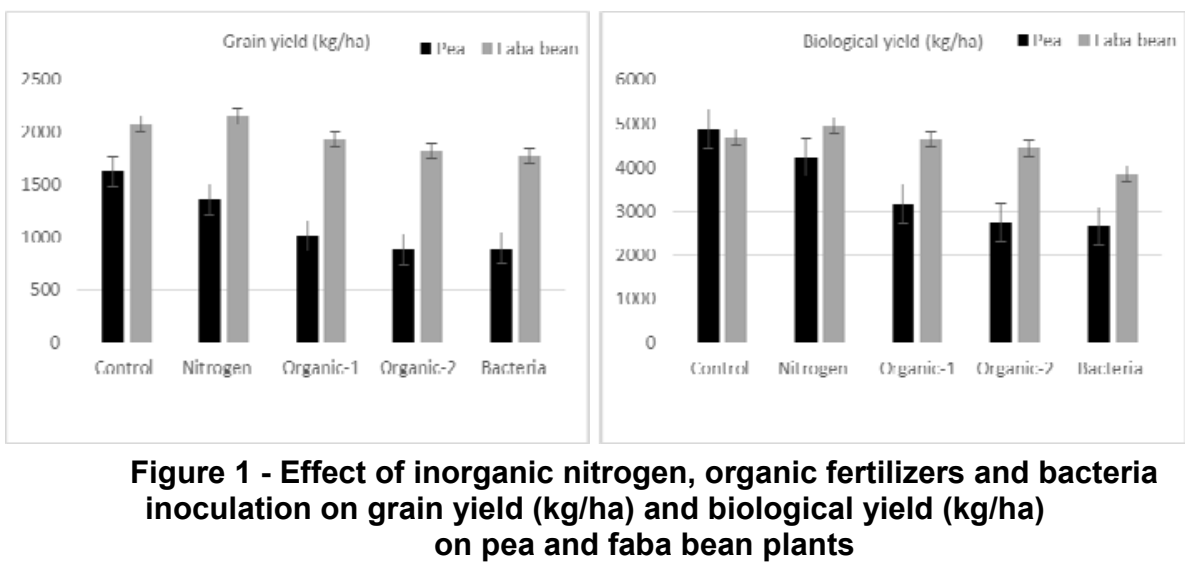

The highest plant biomass (27.3 g) and seed yield per plant (14.1 g) on faba bean was observed from bacteria inoculation, and differ from control (23.8 g for plant biomass and $12.6 \mathrm{~g}$ for seed yield per plant). The differences among other treatments for plant biomass on faba bean were no significant. The lowest seed yield per plant $(8.9 \mathrm{~g})$ on faba bean was in Organic-2 treatment. The maximum seed yield per plant $(7.0 \mathrm{~g})$ on pea was in control, compared to other treatments (Fig. 2). In our study, organic treatments showed poor performance for plant traits, however, Dawood et al. (2019) noted that humic acid caused the highest significant increases of all vegetative growth parameters relative to control. The effect of inorganic nitrogen, organic fertilizers and bacteria inoculation on number of seeds per plant on pea and plant pod weight on faba bean was significant. The highest number of seeds per plant (26.1 seeds/plant) on pea was obtained from control, and treatments (Organic-1, Organic-2, nitrogen and bacteria inoculation) had decreased the number of seeds per plant. Plant pod weight ranged from $11.7 \mathrm{~g}$ to $17.4 \mathrm{~g}$ on faba bean. The maximum pod weight was in bacteria inoculation, and the lowest value was in Organic-2 treatment (Fig. 3). Otherwise, Sunday and Asaba (2018) reported that low pod yield recorded under control plots. 


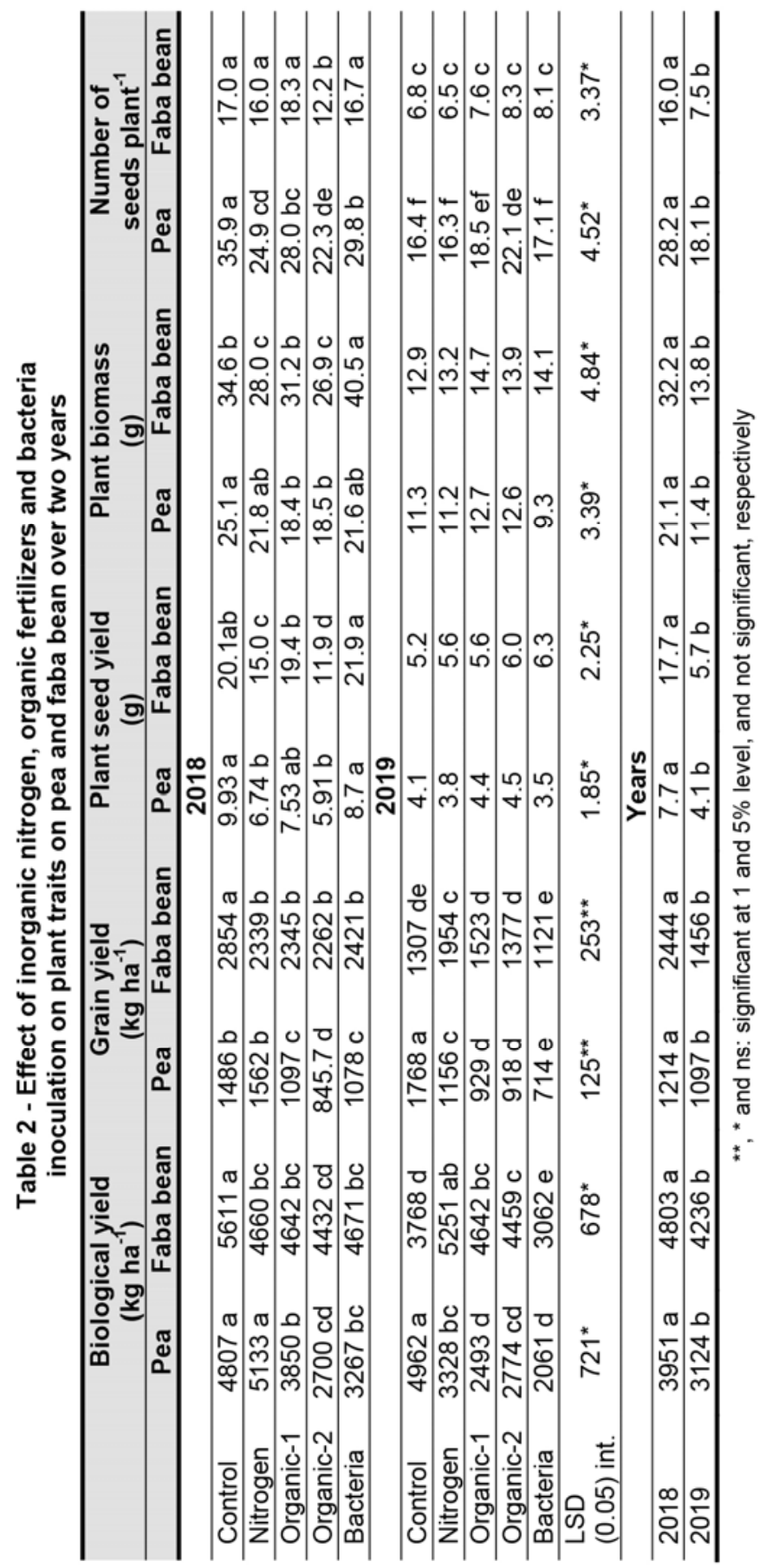




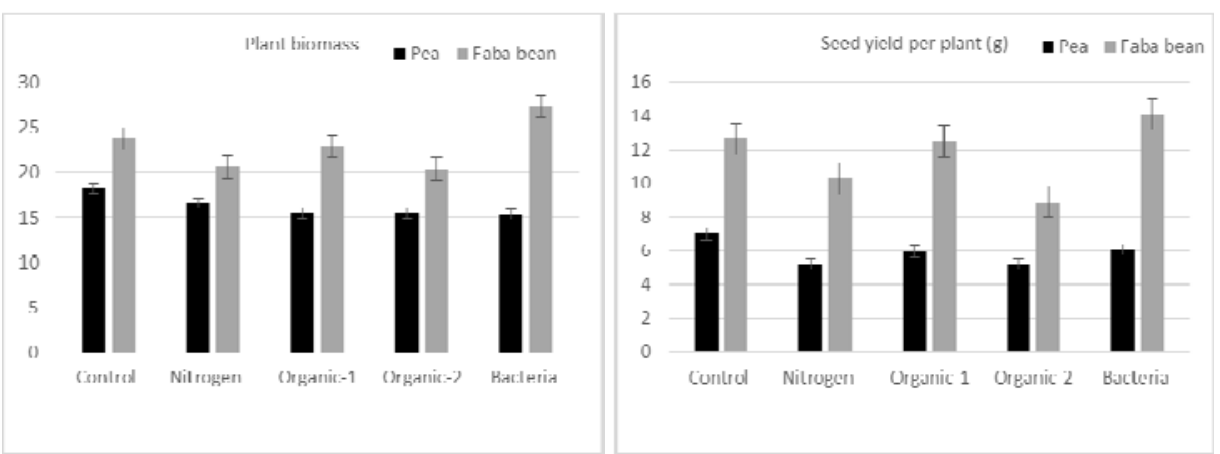

Figure 2 - Effect of inorganic nitrogen, organic fertilizers and bacteria inoculation on plant biomass per plant $(\mathrm{g})$ and seed yield per plant $(\mathrm{g})$ on pea and faba bean plants
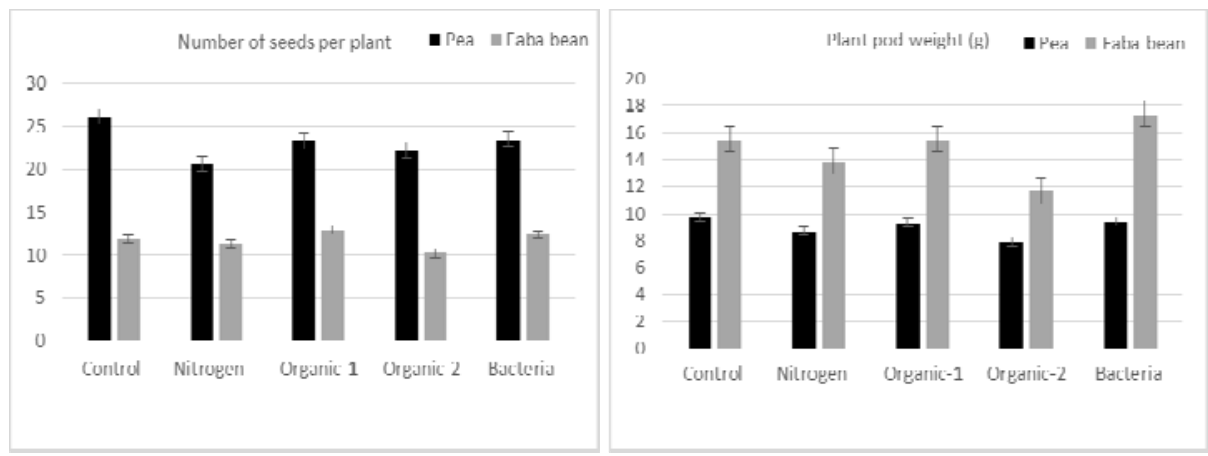

Figure 3 - Effect of inorganic nitrogen, organic fertilizers and bacteria inoculation on number of seeds per plant and plant pod weight per plant $(\mathrm{g})$ on pea and faba bean plants

Differences among years and treatment $\times$ year interaction were significant for number of seeds per plant and pod weight, both faba bean and pea (Table 2).

Some authors noted that high of nitrogen fertilization with rhizobium inoculation reduced nodulation which brought about a reduction in yield parameters (Brkić et al., 2004).

Organic-1 and Organic-2, despite of humic compounds, were exhibited low performance, but Moraditochaee (2012) noted that humic acid significantly increased seed yield, straw yield and biological yield of peanut. Kumar et al. (2005) stated that biological fertilizers with low rates of chemical fertilizers on sesame significantly increased the number of capsules per plant and seed yield. Taylor and Smith (1992) reported that increasing nitrogen up to $200 \mathrm{~kg} \mathrm{~N}$ ha significantly increased the number of pods per plant. If the amount of nitrogen is much less favorable for plant growth and nitrogen removed from mature leaves and young parts transmitted, in this case nitrogen deficiency symptoms, such as 
accelerated aging can be seen in older leaves (Pashaki et al., 2016).

The effect of inorganic nitrogen, organic fertilizers and bacteria inoculation on fresh nodule weight was significant on pea. The highest fresh nodule weight on pea was in bacteria inoculation (0.8 g), but Organic-1 (0.5 g), Organic-2 (0.4 g) and nitrogen $(0.45 \mathrm{~g})$ treatments were no differ from control $(0.5 \mathrm{~g})$. Surprisingly, any fertilizer addition did not enhance the dry nodule weight of peas and faba bean (Fig. 4).

Year and treatment $\times$ year interaction for fresh nodule weight on pea and faba bean was significant (Table 3). Giller and Cadisch (1995) reported that small amounts of available soil or fertilizer $\mathrm{N}$ have often been shown to have a stimulatory effect on legume nodulation and $\mathrm{N}_{2}$ fixation. However, Namvar et al. (2011) revealed that the presence of high rates of $\mathrm{N}$ can inhibit the nodulation and symbiotic $\mathrm{N}$ fixation in legumes. Similarly, David and Khan (2001) reported that addition of nitrogen to the soil severely depressed the nodulation on chickpea (Cicer arietinum).

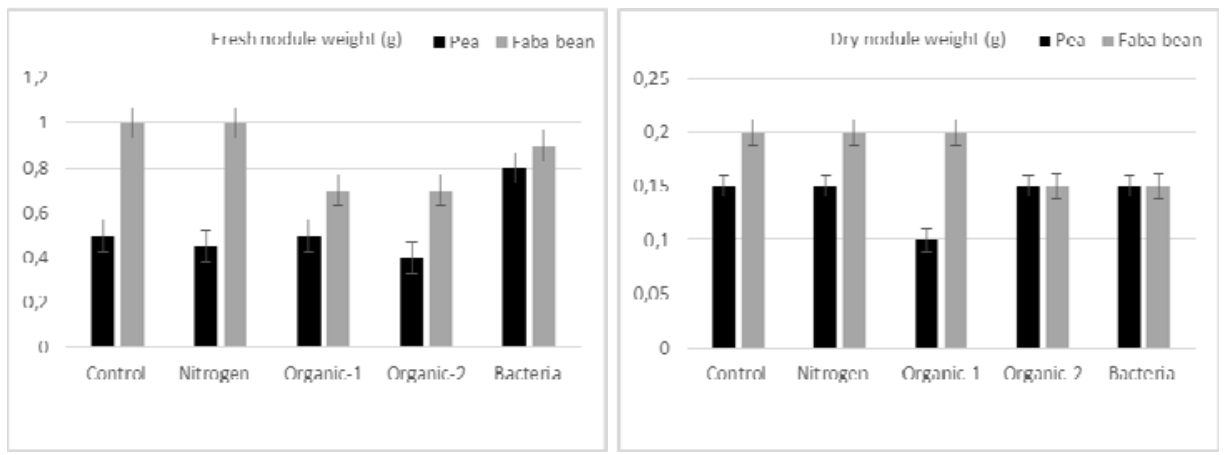

Figure 4 - Effect of inorganic nitrogen, organic fertilizers and bacteria inoculation on fresh and dry nodule weight per plant $(\mathrm{g})$ on pea and faba bean

Theeffect of treatments on number of nodules per plant on pea and faba bean was significant. The highest number of nodules per plant on pea was in bacteria inoculation (125.9) and control (121.5), and differences among nitrogen (109.1), Organic-1 (97.3) and Organic-2 (109.3) treatments was no significant. In faba bean, the highest number of nodules per plant was in nitrogen treatment, but Organic-1 (111.6), Organic-2 (113.2) and bacteria (130.0) treatments were no differ from control (128.0) (Fig. 5). Year and treatment $x$ year interaction for number of nodules per plant at both pea and faba bean was significant (Table 3). Olivera et al. (2002) reported that rhizobium inoculation increased positive effect on number of nodes and nitrogen fixation in faba bean. Organic fertilizer addition significantly reduced nodules of pea in the field. 


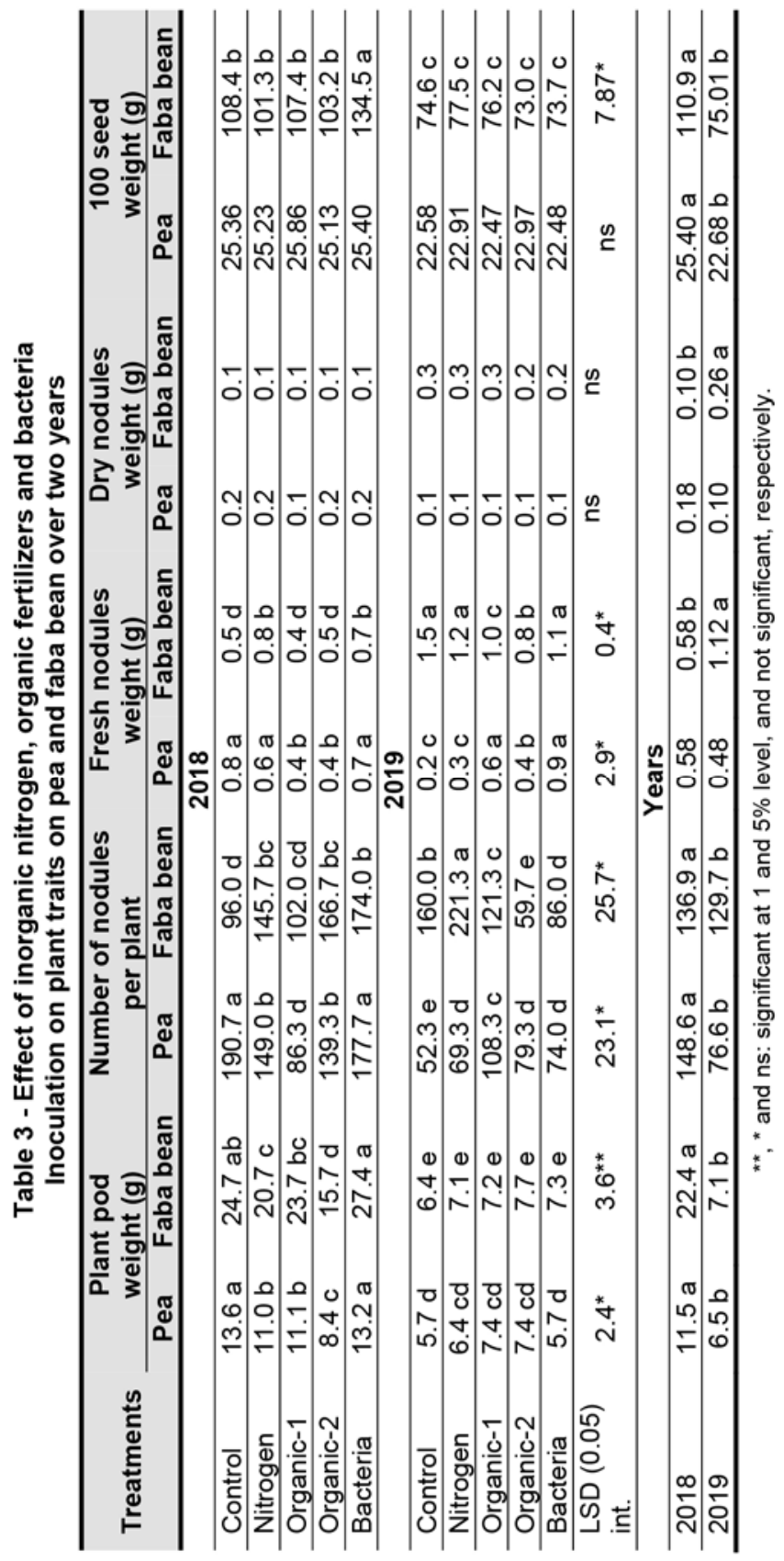




\section{ORGANIC AND INORGANIC FERTILIZATION ON FABA BEAN AND PEA}
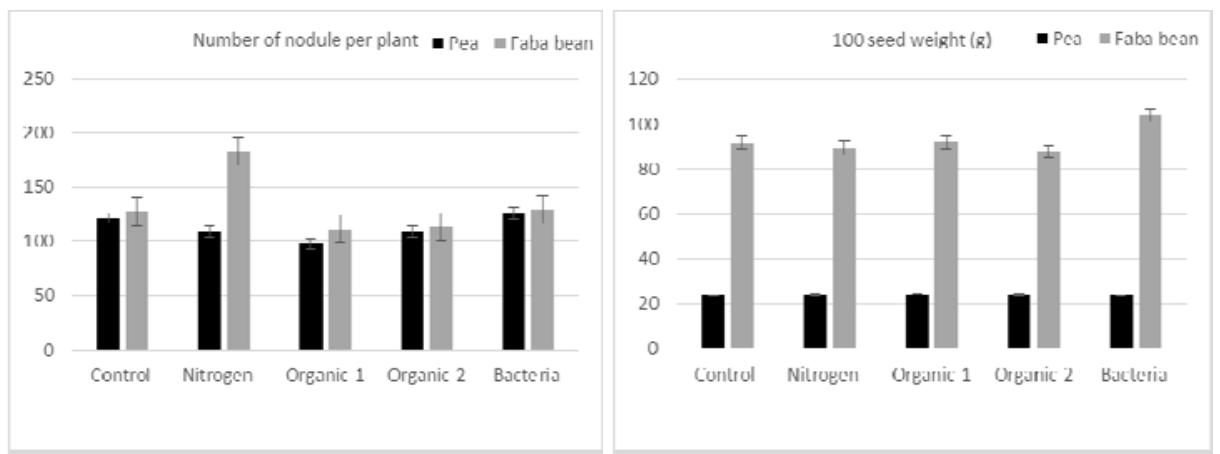

Figure 5 - Effect of inorganic nitrogen, organic fertilizers and bacteria inoculation on number of nodules per plant and 100 seed weight on pea and faba bean

One explanation for the present results would be an increased microbial competition in the rhizosphere. Another possible explanation would be that the addition of available nutrients, especially humic acid in Organic-2 fertilizer, decreases the dependency of plants on nodule (Marschner et al., 2004). The maximum 100-seed weight (104.1 g) on faba bean was in bacteria inoculation, but nitrogen (89.4 g), Organic-1 (91.8 g) and Organic-2 $(88.1 \mathrm{~g})$ treatments were no differ from control $(91.5 \mathrm{~g})$. The effect of treatments for 100 seed weight on pea was no significant (Fig. 5). Treatment $\times$ year interaction for 100 -seed weight faba bean was significant.

\section{CONCLUSION}

It is recommended to apply plant nutrients in soils with low organic matter content. In organic fertilizer applications, especially application dose should be adjustment well. There is no need for bacterial inoculation in soils with special bacterial race.

\section{REFERENCES}

Adesemoye, A.O., Torbert, H.A. \& Kloepper, J.W. (2009). Plant growth-promoting rhizobacteria allow reduced application rates of chemical fertilizers. Microb Ecol, 58: 921-929.

Adesemoye, A.O. \& Egamberdieva, D. (2013). Beneficial effects of plant growth-promoting rhizobacteria on improved crop production: prospects for developing economies. In: Bacteria in agrobiology: Crop productivity, pp. 45-63, Springer, Berlin, Heidelberg.

Albayrak, B.Ç., Biçer, B.T. \& Pirinç, V. (2015). The effect of different fertilizer forms in pea (Pisum sativum L.) on yield and yield components. International Symposium For Agriculture And Food (ISAF), Ohrid, 2015.

Brkić, S., Milaković, Z., Kristek, A. \& Antunović, M. (2004). Pea yield and its quality depending on inoculation, nitrogen and molybdenum fertilization. Plant Soil Environ., 50(1): 39-45.

David, J. \& Khan K.S. (2001). Effect of nitrogen application on nodulation in inoculated chickpea (Cicer arietinum L.). J.Biol.Sci., 1(3): 87-89, DOI: 10.3923/jbs.2001.87.89

Dawood, M.G., Abdel-Baky, Y.R., ElAwadi, M.E.S. \& Bakhoum, GS. 
(2019). Enhancement quality and quantity of faba bean plants grown under sandy soil conditions by nicotinamide and/or humic acid application. Bull.Natl.Res.Cent., 43(1): 28-39, DOI: 10.1186/s42269019-0067-0

Elsheikh, E.A.E. (2011). Environmental soil ecology, Khartoum University Press.

Giller, K. \& Cadisch, G. (1995). Future benefits from biological nitrogen fixation an ecological approach to agriculture. Plant Soil, 174(1): 255277, DOI: 10.1007/BF00032251

Khurana, A.L. \& Dudeja, S.S. (1997). Biological nitrogen fixation technology for pulses production in India. Indian Institute of Pulses Research, Kanpur, India.

Kumar, S, Rawat, C.R, Dhar, S. \& Rai, S.K. (2005). Dry-matter accumulation, nutrition uptake and changes in soil fertility statues as influenced by different organic sources of nutrients to forage sorghum. Indian J.Agric.Sci., 75(6): 340-342.

Lal, H. (2004). Effect of nitrogen and phosphorous on seed yield of pea (Pisum sativum L.) and French bean (Phaseolus vulgaris L.). Progress. Hortic., 36(1): 150-151.

Marschner, P., Crowley, D. \& Yang, C.H. (2004). Development of specific rhizosphere bacterial communities in relation to plant species, nutrition and soil type. Plant Soil, 261(1): 199-208, DOI: 10.1023/B:PLSO.000 0035569.80747.c5

Milaković, Z., Brkić, S., Bukvić, Ž., Bogut, I. \& Horvat D. (2000). Efficiency of inoculation and different nitrogen fertilization on small-grained bean quality and yield. Rostl. Výr.UZPI (Czech Republic), 46: 361366.

Mishra, A., Prasad, K. \& Rai G. (2010). Effect of bio-fertilizer inoculations on growth and yield of dwarf field pea (Pisum sativum L.) in conjunction with different doses of chemical fertilizers. J.Agron, 9(4): 163-168, DOI: 10.3923/ja.2010.163.168

Moraditochaee M. (2012). Effect of humic acid foliar spraying and nitrogen fertilizer management on yield of peanut (Arachis hypogaea L.) in Iran. J.Agric.Biol.Sci., 7(4): 289-293

Namvar, A., Sharifi, R.S., Sedghi, M., Zakaria, R.A., Khandan, T. \& Eskandarpour B. (2011). Study on the effects of organic and inorganic nitrogen fertilizer on yield, yield components, and nodulation state of chickpea (Cicer arietinum L.). Commun. Soil Sci. Plant Anal., 42(9): 1097-1109, DOI: 10.1080/00 103624.2011.562587

Ngeno, J., Chemining'wa, G.N., Muthomi, J.W. \& Shibairo, S.I. (2012). Effect of Rhizobium inoculation and nitrogen fertilizer application on growth, nodulation and yield of two garden pea genotypes. J.Anim. Plant Sci., 15(2): 2147- 2156.

Olivera, M., Iribarne, C. \& Lluch, C. (2002). Effect of phosphorus on nodulation and $\mathrm{N}$ fixation by bean (Phaseolus vulgaris). Proceedings of the 15th International Meeting on Microbial Phosphate Solubilization. Salamanca University, 16-19 July, Salamanca, Spain.

Pashaki, K.M., Reza, M.G., Boroumand, H. \& Majidian, M. (2016). The effect of the combined chemical, bio and vermicomposting fertilizers on yield and yield components of Vicia faba L. EOJNSS, 5(3): 683.

Patil, R., Kadam, A.S. \& Wadje, S.S. (2011). Role of potassium humate on growth and yield of soybean and black gram. Int.J.Pharm.Bio.Sci., 2(1): 242-246.

Servani, M., Mobasser, H.R., Sobhkhizi, A., Adibian, M. \& Noori, M. (2014). Effect of phosphorus fertilizer on plant height, seed weight and number of nodes in soybean. Int.J. Plant, Anim.Environ. Sci., 4(2): 696700. 


\section{ORGANIC AND INORGANIC FERTILIZATION ON FABA BEAN AND PEA}

Silsbury, J.H. (1990). Growth, nitrogen accumulation and partitioning, and $\mathrm{N}_{2}$ fixation in faba bean (Vicia faba cv. Fiord) and pea (Pisum sativum cv. Early Dun). Field Crop.Res., 24(3-4): 173-188, DOI: $10.1016 / 03$ 78-4290(90)90036-B

Solomon, W.G.O., Ndana, R.W. \& Abdulrahim, Y. (2012). The comparative study of the effect of organic manure cow dung and inorganic fertilizer N.P.K on the growth rate of maize (Zea mays L.). Int.Res.J.Agric.Sci. Soil Sci., 2(12): 516-519.

Sunday, N. \& Asabar, K. (2018). Response of yield and yield components of field pea (Pisum sativum L.) to application of nitrogen and phosphorus fertilizers. Int.J.Sci.Res.Publ., 8(8): 14-19, DOI: 10.29322/IJSRP.8.8.2018.p8004

Taylor, A.J. \& Smith, C J. (1992). Effect of sowing date and seeding rate on yield and yield components of irrigated canola (Brassica napus L.) grown on a red-brown earth in south-eastern Australia. Aust.J. Agric.Res., 43(7): 1629-1641, DOI: 10.1071/AR9921629

Vessey, J.K. (2003). Plant growth promoting rhizobacteria as biofertilizers. Plant Soil, 255(2): 571586, DOI: 10.1023/A:1026037216 893 